\title{
The Origins of the Institutionalised Guilty Plea in the United States: Some Lessons from History
}

Mike MCCONVILLE

\section{Introduction}

In this lecture, I want to talk about the origins of the modern system of criminal justice in the United States of America. In particular, I will talk about how it became transformed in the nineteenth century from one in which the routine method of case disposal was by means of a jury trial to one in which, by 1860 , the guilty plea was dominate. One of the purposes of my talk is to explain how this fundamental transformation came about. This, however, is of lesser significance than a second objective: this is to show the importance of theory, of historical method and of the value of "law in context" as a method of analyzing law. It is appropriate that "law in context" should be given its proper recognition because it has been the foundation stone and lasting achievement of the School of Law at Warwick which pioneered this approach to legal studies some 25 years ago.

\section{The Traditional Account}

According to America legal historians such as Lawrence Friedman, John Langbien and Malcom Feeley, the American criminal justice system in the first half of the nineteenth century relied upon jury trials because the system as a whole was populated by amateur actors. In the absence of professional police, lawyers and judges, justice in criminal cases was heavily dependent upon luck and chance. In such a system, whilst no method of deciding upon outcome could produce reliable results, the jury was as good a method as any for reaching a verdict and, at least it had the merit of being "democratic". As Lawrence Friedman and Robert Percival put it: 
"In a system run by amateurs, or lawyers who spent little bits of their time and energy, with no technology of detection or proof, a trial was perhaps as good a way as any to strain the guilty from the innocent" (The Roots of Justice, 1981, p. 194).

The picture which emerges is of a system of justice which was unplanned, spontaneous and primitive. Any evidence had to be gathered together by the parties themselves. The private parties to the dispute collected together whatever witnesses they could and produced them for the first time on the day of the trial itself. Witnesses told their story to the jury without the assistance of lawyers and without the benefit of a framework of rules of procedure or evidence. The jury might listen to several cases one after the other before giving a series of verdicts without retiring to deliberate. In this setting, trials were very wasteful of public resources and often amounted to little more than "slow guilty pleas" in which the conviction of the unrepresented defendant was a foregone conclusion.

According to the traditional account, the method of resolving disputes changed with the growth of professionalism. The first important development was the emergence of police science. As police professionalism grew, the police were able to use more scientific method of detection with the result that evidence became more reliable. As police investigation improved and evidence became more reliable, so lawyers emerged. These lawyers, who understood legal and procedural issues, were able to assess the value of items of evidence. They could sort cases into, on the one hand, those which (because of reliable police or forensic evidence) were so compelling or persuasive that a conviction was inevitable and, on the other hand, those where the outcome was not at all clear because no persuasive scientific proof was available. For the former group of cases in which a conviction was inevitable and entirely appropriate, these lawyers developed a system of guilty pleas based upon the reduction of charges or of sentence. This new plea bargaining system, thus, enabled courtroom actors to adjust the sentence to suit the individual circumstances of the defendant and to reward those who were willing to avoid wasting court time and public money by giving them a reduced sentence. By contrast, in those cases where the outcome was not clear, this new band of professional lawyers used their adversarial or trial skills to fight cases on procedural, evidential or legal grounds. 


\section{The Attractions of the Traditional Account}

On the face of it, this traditional account has a number of attractive features, which may be summarized as follows:

a) First, the transformation of the criminal justice system is explained as an entirely rational process.

b) Second, the change to the system is seen to be the product of a combination of science and professionalism, both of which appear as objective and beneficial.

c) Third, all the principal criminal justice actors and institutions emerge triumphant: the police as the creators of reliable evidence; lawyers as the group able to reliably sort the guilty from the potentially innocent; judges as guarantors of the overall fairness of the process including the sentencing system; and the guilty plea itself as entirely appropriate and benign.

d) Fourth, legal history becomes a story of progress in which everyone benefits.

\section{The Problems with the Traditional Accounts}

Despite its superficial atractiveness, the account of legal historians has a number of serious limitations which cast doubt upon its validity. There are concerns at both the empirical or factual level, and also at the conceptual or theoretical level:

a) At the empirical level, commentators such as Friedman, Feeley, Langbein, Alschuler and Mather produce little or no empirical support for their account of how the system changed. For example, no evidence is produced in support of the view that the rise of the guilty plea was linked to and dependent upon the discovery of improved and "scientific" techniques of evidence gathering. Instead, commentators simply assert that evidence became more reliable through the emergence of fingerprinting, ballistics, blood testing and the like.

Again, the use by these legal historians of the term "amateur" to describe courtroom actors, is not based upon any systematic analysis of the background, qualifications or skills of the actors in question. Instead, it is a characteristic which is ascribed to police, lawyers and judges on the basis of an assumption that they were not regularly present at trials and that they possessed no relevant investigative or legal skills. 
b) At the theoretical level, the explanatory power of the theory advanced by commentators rests entirely on the assumption that social change is always a history of progress in which primitive and outdated institutions are replaced by advenced, modern and efficient forms. Since, however, this is simply asserted rather than demostrated, the result is to blur the boundary between theory and ideology.

A second theoretical problem is that the traditional account detaches the criminal justice system from the wider society. Changes in the state or the political economy, even if they were to be acknowledged, are not seen as having any influence upon the legal system. In this account, science becomes the agent of change to which the criminal justice system, with its own internal coherence and logic, responds in ways which are claimed to be beneficial. The reason why this process operates in this way is not, however, explained.

\section{Testing the Traditional Account: New York City}

Together with my colleague Professor Chester Mirsky of New York University, I have been engaged for the last ten years in testing the traditional account. Our work has been based on the Court of General Sessions in New York City, one of the oldest and most prestigeous legal institutions in the USA. Our study has been upon a systematic examination of original material going back to the start of the nineteenth century. The material we have examined includes files created by the District Attorney, which consist of the complaint, statement of witnesses, records of the examination of defendant, the indictment and real evidence in all cases prosecuted from 1804 . In addition, we have analyzed Court Minute Books, which record the type and number of indicred cases disposed of on a daily basis, the number of defendants, lawyers and judges, the method of disposition, and outcome. We also had access to reports of courts reporters, official statistics gathered from 1830 onwards, and contemporary reports of individuals and agencies.

With this material, we are able to provide a systematic analysis of the system of criminal justice from 1800 when cases were decided by jury trial to 1860 and beyond by which time the guilty plea had come to dominate court outcome. For the purpose of analysis, we have divided our account into two periods, that from 1800-1845 the era of the jury trial; and that from 1845 onwards as guilty plea rapidly grew to a position of dominance. 


\section{Individualism and the Mercantile Economy 1800-1845}

\subsection{Individual Justice}

Over the first half of the nineteenth century, New York City was a busy sea port with a population which grew from some 60,000 in 1800 to over 300,000 by 1840 . Whilst there were vast inequalities of wealth between merchants and landed gentry on the one hand, and a large labouring and propertyless artisan class on the other, the political economy rested upon a benevolent, paternalistic administration. The emphasis was upon consensus and the common good, with free market principles emphasizing the importance of the individual citizen. It was the individual citizen who was seen as the building block of society, with the state being seen as a potentially intrusive force.

Criminal justice entirely reflected this philosophy of individualism. The jury was seen as central to the administration of justice, not because it was as good as any other decision-making body in a primitive system, but because it was seen as the ultimate guarantee against unrestrained state interest. It was the protector of the individual; the lamp that showed that freedom lives; a little parliament that enabled people to govern themselves. And "govern" is what the jury could do in a real sense. Indeed, at least until 1830, the jury decided both fact and law.

Whilst jury veredicts might occasionally excite critical comment in the newspapers or among local politicians, there was no independent state interest in the outcome of court cases. No official statistics were collected either on criminality in the population or on the patterns of veredicts at courts. Justice was seen to an individual matter. The courts were provided as a service to the individuals who could use them, as private prosecutors, to obtain justice. And it was the job of those responsible for running the courts to ensure that this neutral venue was available to those who could not otherwise secure justice through settling the matter out of court or in some other way.

\subsection{The Investigation of Crime}

In the first half of the nineteenth century, responsibility for preventing and investigating crime lay with constables and watchmen organized on a highly local basis. In practical terms, prosecutions were heavily dependent upon the actions of private citizens laying a complaint, acting as witnesses or actually making an arrest. The official policing system 
would respond to citizen's request and, very occasionally, engage in crime prevention by laying traps to catch suspected offenders.

\subsection{Magistrates' Court}

Trials were not, as commentators have alleged, spontaneous events which were thrown together on the day of trial. Once a suspected criminal was brought before the court, a magistrate, assisted by a clerk, would screen the case to ensure there was sufficient evidence or, if there was not, to dismiss the case.

Magistrates took statements of evidence from the complainant, from witnesses and from the person who was being accused. These statements were taken under oath and would be the basis for evidence at trial. Additionally, magistrates could issue warrants for constables to search premises for stolen goods and they might supervise such searches. The evidence gathered by the magistrate formed the basis of a file of evidence which was transmitted to the District Attorney who could then present the case to the Grand Jury when requesting an indictment or formal bill of charge. To ensure that a meaningful trial would take place, the magistrate could take security, in the form of money, from both witnesses and defendants to ensure that they turned up for trial. If a witness or defendant was without means, the magistrate could and did order their detention in prison until the trial.

\subsection{Lawyers}

Contrary to the view of commentators who see this period as an unlawyered era, trained lawyers existed as a routine feature of the administration of criminal justice. For the prosecution, the District Attorney was a prominent lawyer who was initially appointed by the Governor and later by the judges. The District Attorney assumed the role of Minister of Justice. It was his job to guide the case through to completion without striving for a particular result. Whilst the District Attorney took cases himself, he could also instruct private lawyers to act for the prosecution and, when he did so might prepare a brief for them as to what witnesses would say and how the case might be presented.

Certainly we know that from 1810 onwards, defence lawyers appeared in almost all trials. The New York State Constitution had as early as 1789 guaranteed each defendant the right to a lawyer, and the records show that defendants were given this entitlement. This was so whether 
the defendant could pay or, as in most cases, was without means. These lawyers were not amateurs but trained in law and knowledgeable in law and procedure. Some wrote treatises on substantive and procedural law and they were commonly instructed to act on the part of the prosecution.

The assertions of legal historians about the state of legal representation are, therefore, contradicted by the plain facts.

\subsection{The Trial Process}

As I have mentioned, according to traditional accounts jury trials in the first half of the nineteenth century were spontaneous, short and chaotic events to get a decision on the facts. This is very far from the truth:

- Trials often involved detailed argument on law. Indeed, the purpose of a trial in some cases was to stablish the law, to resolve uncertainly and to provide clarity for the commercial world.

- Prospective jurors could be challenged, witnesses examined and cross examined.

- Motions to dismiss the charge, to discharge the defendant, to stay sentence or to set aside the verdict were reasoned and subject to detailed rules.

- Judges marshalled the evidence and often gave a view as to whether the prosecution case had been established or whether the defendant should be acquitted. The jury generally followed the judge's advice on issues of law and, commonly, on issues of fact. It is not remarkable, therefore, that in 80 per cent of cases between $1800-1830$ that the jury was able to bring in a verdict without retiring to discuss the case.

This does not mean that jury trials were the site of great legal battles in which skilled and aggressive defence lawyers would attack witnesses or engage in adversarial wars. The style of cross-examination was respectful and less confrontational than today. Lawyers operated a code of ethics which might lead them to withdraw a defence or abandon to altogether should prosecution evidence be clear and convincing. Rather, the basic principle of the trial and also the task of the lawyer was to ensure that veredicts were obtained only in conformity with the accepted rules of law, procedure and evidence. 


\section{Aggregate Justice: The Pre-Industrial Economy 1845-1865}

From the 1840s, New York City was transformed in size and in population mix. By 1850 , it had become the largest city in the western hemisphere with a population in excess of half million people. Massive waves of immigration from Ireland, Germany, England, France and elsewhere resulted in a city in which poverty was rampant, with people living in squalid tenement buildings. Alcoholism was a major social disease and crime rife.

Of most enduring significance was the institutions of criminal justice and crime itself were to become politicized. Judges now became elected instead of appointed. The District Attorney also became an elected official (in 1846) with clear links to party politics. Official statistics began to be collected (first published in 1840) which sought to measure the level of crime in society and the background and charactel ristics of those convicted of crime. Soon these statistics focused on race and crime quickly became politicized around the foreign-born. The new immigrant was seen to be criminal and dangerous, a threat to the existing social order.

As a statistical report to the Secretary of State (in 1856) put it:

"A large proportion of [immigrants] are shipped as criminals. Foreign monarchies and despotisms find it cheaper to pay the passage of criminals to this country, than to support and guard them at home, and so empty their jails and prisons... to swell the records of crime [in this country] and shock the public... with deeds of violence."

The result was a transformation in the attitude towards justice. Justice was no longer an individual issue; rather, the concern was with overall or aggregate outcome. Whereas the focus had been on the individual case, now it was on the pattern of crime, the control of the dangerous classes and the efficiency of the system in convicting those arrested. And it was this shift political sentiment which underlay the transformation of criminal justice for all time, a transformation made possible by new institutional arrangements to which I now turn.

\subsection{Police and Magistrates}

Contrary to the views of commentators, over the second half of the nineteenth century, the nature of policing did not change with the advance of science. The science of detection was never more than of 
marginal significance. Fingerprinting did not emerge until the 1860 s, neither photographs not the telegraph were regularly used, and ballistics and blood testing made no impact on detection. Whilst the administration of the police became more centralized, it had little effect upon law enforcement at this time.

What changed was that the police now became identified with the prosecution case. They quickly displaced the private prosecutor or complainant by assuming ownership of cases. Every case became assigned to a named officer or officers, and, unlike in the first half of the nineteenth century, any contribution the police made to the case was supported by a police witness statement. Though the substantive involvement of the police remained the same, the passing of ownership of cases to the police was the first clear that crime was now a public matter in which the state had a clear and deepening interest.

\subsection{Judicial Control of the Jury}

The second significant change was that judicial control of the jury began to wane as eligibility for jury service based on property qualifications was abolished. This enabled labourers to serve on juries and meant that the close ties berween the judge and the merchant juror class of the early part of the century were now broken. As a result of this change in composition, juries retired more often to consider their veredicts, the acquittal rate increased and where convictions were achieved they tended increasingly to be in respect of reduced charges. For a state interested in law and order and the certaintly of conviction, reliance upon this new jury was undesirable.

\subsection{District Attorney}

The most significant change, however, occurred within the office of the District Attorney. This became transformed from a minister of justice to an elected official whose interests were now openly aligned with those of the state. As the state began to focus upon the foreign-born and the "dangerous classes", concerns over law and order became the responsibility of the District Attorney. The District Attorney became identified with the effectiveness of crime control, with the outcome of cases in court and thus with the conviction rate.

Responsibility for law and order, which was once dispersed, thus became focused on the office of the District Attorney. This had greater 
significance because, whereas prosecutions had earlier been managed by private attorneys as well as the District Attorney's office prosecuted in all cases. The District Attorney was now solely responsible for the efficient and effective prosecution of cases in court.

To assist in fulfilling this role, the District Attorney developed a new philosophy towards criminal prosecutions. As state concern over crime increased and as judicial control of the jury weakened, a new mechanism was needed to consolidate or increase the conviction rate. This was achieved by a new "half-loaf" philosophy: the District Attorney increasingly gave up efforts to get a conviction of the full offence before a jury and, instead, offered defendants a plea to a lesser offence and thus a reduced sentence. In this way, the plea bargain was born. The result was that within a few years and by 1860 , the guilty plea became the dominant method of case disposition. The "lesser plea" which was invented to satisfy the state's new-found need to get aggregate convictions was to be an enduring legacy which still dominates American criminal justice today.

\subsection{Defence Lawyers}

As the District Attorney's office became politicized, so private lawyers became confined to working for the defendant. Whilst they became increasingly identified with defendants, they did nor fight cases more vigorously at trial and, instead, spent their efforts in counselling defendants to accept lesser plea offers and the reduced sentence that went with them. Over time they lost status and prestige as the criminal lawyer became associated with the people they represented. In the result, they never were able to be a counterweight to the new order laid down for the handling of criminal cases by the prosecutor.

\section{Summary and Conclusion}

As we have seen, from the start of the early nineteenth century criminal trials were rational legal events involving narrow questions of law and fact. They were not chaotic and spontaneous but planned and orderly. They were not run by amateurs but by trained personnel, magistrates, lawyers and judges. Respect was paid to precedent and records were maintained for the purposes of both trials and appeals.

The mistake made by commentators has been to view police and courtroom actors in static terms, isolated from the wider society and 
responsive only to advances in science. Even if advances in science of a major character had ocurred, it is not likely that we could understand criminal justice without looking at the wider context.

Instead, it is better to see the police and courtroom actors as interrelated entities whose purpose changed over time. Systematic reliance on the guilty plea and plea bargaining emerged as crime became politicized, the jury became less removed from the defendant population, and the District Attorney assumed responsibility for law and order generally and the efficient and effective handling of cases in court. The transformation that ocurred in criminal justice was the result, therefore, of an emerging state interest with the ability to realize its own social and political agenda through new legal forms.

\section{Bibliography}

\section{A. Alschuler}

1979 "Plea bargaining and its history" 13 Law \& Society Review 211

L. FRIEDMAN

1979 "Plea Bargaining in Historical Perspective" 13 Law \& Society Review 246

L. Friedman and P. Percival

1981 The Roots of Justice

M. FEELEY

1982 "Plea Bargaining and the Structure of the Criminal Process" 7 Justice System Journal 338

J. LANGBEIN

1979 "Understanding the Short History of Plea Bargaining" 13 Law \& Society Review 261

M. MCCONVILle and C. Mirsky (forthcoming, 1995)

1995 "The Rise of Guilty Pleas": New York, 1800-1865 22 (45) Journal of Law and Society 443 